\title{
EPISTEMOLOGICAL PARADIGMS IN THE PERCEPTION AND ASSESSMENT OF VERNACULAR ARCHITECTURE
}

\begin{abstract}
The current situation of vernacular architecture is a result of the different perspectives of agents who have some sort of direct or indirect relationship with an architecture of the past which has influenced attitudes and ways of thinking, thus guaranteeing its assessment and survival. Therefore, this article reviews recent currents of thought and theories encapsulating the increased value of vernacular architecture. In the eighteenth century this architecture made the romantic ideals of rural society synonymous with its surroundings, territory, and country. In the twentieth century a select few modernist intellectuals carried out in-depth studies of this architectural type in relation to its formal values. Now, in the twenty-first century, it has become the object of technological and scientific analysis for many experts. The current situation still presents many unresolved problems, which are perhaps the result of little thought having been put into specific aspects of the process of vernacular architecture.
\end{abstract}

Keywords: Vernacular Architecture, Historic Settlements, Tradition, Perception.

\section{Introduction}

The approach proposed here touches upon all aspects of vernacular architecture and aims to act as reference for a latent body of information inherent to the architecture itself. However, on occasion architects approaching rural surroundings to analyse, study, or work in them are completely ignorant of these underlying aspects and limit themselves to purely aesthetic or regulatory aspects learnt within the educational system, but never practiced.

This ground may already seem well trodden speaking strictly in terms of history of art, but what this study aims to establish is new ground for historical reflection as regards interdisciplinary evaluation. This approach must be carried out when investigating the constructed object resulting from situations with no clear historic definition, which have led to the situation of current research on the perception and transformation of vernacular architecture. 
This interpretation of the preservation of vernacular architecture proposes a brief overview of past figurative appropriations involving the idealisation of the object, in contrast with other interpretations found in cultural valorisation processes. An initial examination is made of the anthropological vision of vernacular architecture which interprets historical surroundings as emotionally-charged spaces. This is followed by an analysis of the learning experiences which looked to vernacular architecture as an object of study, until it gradually became iconic for many intellectuals.

In this sense, some researchers have had to take new paradigms into account when attempting to understand vernacular architecture, in the context of each region and its socio-economic, cultural, and educational backgrounds. It can be seen as a product of logical sequences, which do not always follow pre-established solutions in the search for a way to understand how vernacular architecture is affected at present. These new paradigms probably require critical interpretations that apply to challenges and expectations at local level, without whitewashing their realities and avoiding false perceptions or simplistic attitudes, which merely encourage the creation of utopias or idealised prestige.

The paper seeks to understand the sense of acculturation in which performative actions may mould local realities, where planning is in opposition to collective consciousness. Thus, after a fleeting glance at the urban approach to rural spaces, it suggests a way towards multiple options for approaching, discussing, and assessing the extremely complex polarisation of vernacular architecture.

There is a patent need for a calm and thorough analysis of the transformation processes undergone by rural nuclei and the loss of traditional forms of construction. Although this research involves quite a few resources from social sciences, this analysis should not take the form of a nostalgic examination of a pre-industrial past but that of an educational reflection which helps promote a conservative and innovative methodology for a society which craves modernity and development.

In short, the paper discusses a conflict that does not focus on specific persons or cases, but rather is a critique of behaviour widespread in some countries eager to feign a sociocultural development which most of the time is devoid of content or a solid cultural foundation. 


\section{Phenomenology of romanticism, Heimatschutz as identity}

Nietzsche defined humanity as 'without a homeland' as a 'still rootless animal', ${ }^{1}$ in reference to the absence of folk and traditional knowledge, and placed humans within 'nature' or 'cosmos'. Heidegger, seeking a way to provide a background for the symbolic resources characteristic of the concept of Heimat, argued the need to think about our existence and lack of homeland. He appropriated the term Heimatlogskeit to describe the condition of humans in the age of technology (Zugni-Tauro 2000, p. 184). From this point on, the word Heimat and associated symbolic images, combined with memory in the search for closeness, roots and tradition. ${ }^{2}$

The concept of Heimat brought about in-depth psychological and emotional analysis of the term, based on sensitivity, experience and compatibility with the cultural environment. Eduard Spranger, one of the Heimat experts in the 1920s, believed that people could find Heimat in some place other than their birthplace through work and spiritual involvement. This showed that Heimat was not an actual place, but rather a subjective mood resulting from a relationship between human beings and locations. ${ }^{3}$ Spranger used politically-moderate terms to suggest that what defined a people was language, while Fichte saw this as Gëmut, the indefinable catalogue of the mind and the product of cultural history shared throughout history.

In this context, the experiences of space lived in - as linked to sensations, personal images, recollections and memory - connect with a series of moments with close ties to specific personal and social contexts. In vernacular architecture, the subject manages to identify historical objects through personal images as well as through subjective perceptions relating to era, memory and imprints. Therefore, this experience is a game of mutual empathy between the location, its history, and the experience reflected within its walls, or between subject and recollections. All of these are influenced by the sensations and emotions of individual observers.

Accordingly, German romanticism placed special importance on instilling a single moral standard based on customs and traditions within the family, and based on history and connections within the social sphere. ${ }^{4}$ The aim of this was to form a virtuous social character that individuals would value and recreate in order to strengthen national character in their own personal Heimat. The term spread from the field of natural sciences to those of anthropology, sociology, psychology, philosophy, religion and literature, as well as political discourse. Its broad meaning has made it an everyday term. In reference to the concept of 'identity', or 'related to', Heimat continued to be linked to geographical, social, or moral references that represented identities according to race, 
nation, or religion (Augé 1998, p. 88). For some writers, Heimat was the solid ground on which the words and customs of folk settled, and where ancient customs could be recorded and preserved (Appelgate 1990, p.10).

Heimat was the representation of space and time and embodied a personal connection with the homeland. In this sense, it awarded a feeling of security and belonging and allowed individuals to identify with family, location, country, customs, language or dialect. For Boa and Palfreyman (2000, p. 23), all of these gave meaning to a process of definition or valorisation. At the same time, Heimat encouraged and supported the premodern sense of identity, rooted culture and traditions (Frampton 1982, p. 77).

\section{An anthropological vision of vernacular architecture}

According to German romanticism Heimat widely supports the theory that history was not conceived as a mere succession of specific events. History tells of permanent anthropological interactions between housing, settlements and landscapes (Augé 1998, p. 21). In fact, cultural anthropology has analysed the significance of specific schools of thought on society and location. According to Spranger, Heimat was the 'mechanism for the knowledge of a society and its habitat', where different cultures are studied to understand their forms of representation (González 2003, p. 201). Rapoport (1972, p. 102) believed that human nature contains elements of constancy and change in relation to biological nature, perception and behaviour, which are culturally linked, and therefore, changeable, innate and constant.

In this regard, anthropology has viewed historical surroundings as spaces charged with sensations. This symbolic load aims to aid the interpretation of specific iconographic, ideological and intellectual references. These have played a part in the evaluation of vernacular architecture, both the intrinsic value of the architecture itself, and the factors linking the constructed artefact with the social field, its identity and its history (Augé 1998, p. 19). Accordingly, when studying the geography of terrain, the concept of territory as defined by Ortega (2005) is developed in implicit relation to its meaning of 'inhabitants' or 'as a stock of historicity or a cultural construction' (Martínez de Pisón 2005, p. 47).

As well as referring to the living space itself, this approach expounds, at least in terms of architecture, on the relationships between individuals and their home, work and leisure surroundings, and establishes connections between the subject and shared spaces, the town, neighbourhood, community and, eventually, landscape. This view encompasses an architecture loaded with imprints, some primitive and some developed over generations. This architecture becomes an anthropological place, ${ }^{5}$ both for those who 
inhabit it and for those who study its history and recognise the meaning and weight of tradition in these imprints (Augé 1998, p. 20).

It is worth noting that vernacular architecture can be considered a historical venue in which we can recognise the imprints of an extinct, dead and forgotten past, or as a location where history and tradition remain alive ${ }^{6}$ in daily life. Thus, it could be argued that, as long as history and traditions are kept alive, vernacular architecture becomes an anthropological location, since the value attached to vernacular space can be linked to emotional, existential and mystical factors (Lanternari 1981).

The relationship between humans and Heimat must therefore be viewed from perspectives other than those considered until now. It could be viewed in terms of the study of perception, following the historical connotations of aesthetics and theories on empathy, by researching the devices that allow perceptions free of all subjective influence (Beardsley and Hospers 1976). Alternatively, it could be analysed in terms of Genus Loci, the anthropological ties to cultural and social elements provided by each subject, all of which greatly influence the perception of space resulting from the subjective activity of the mind.

\section{The paradigm of modernity, intellectual discovery}

As Lévi-Strauss (1987, p. 63) pointed out, 'modernity suddenly came about as the source of an industrial revolution which in terms of its breadth, universality and importance of its consequences had only one past equivalent, the Neolithic Age'.

Nineteenth-century pedagogues used education to influence the value and perception of art to encourage sensations in students. The study of popular arts was not a mere pastime or distraction, but the focus of a profound and multidisciplinary education. Thus, the idea of roots persisted in popular art and teachers established connections between vernacular, anonymous and undefined architecture and the deeper roots of the soul of the people.

And so, the ethnography born in Central Europe assumed the visual and personal contact linked to the settlements and people. Romantic euphoria viewed popular art through Heimat, which established connections between nature, society and history. In the early twentieth century, excursions were used for research and teaching purposes in order to further knowledge of popular works of art and nature. It was thought that this method benefitted the intellectual development of students and provided freedom and serenity to observe and contrast impressions (Xirau 1969, p. 42, see figure 1). 
Different choices were put into practice depending on the learning experience arising from the object studied. Accordingly, different perceptions and interpretations were available and were all considered equal. This meant that they were not questioned as a matter of course, and that the only factors that could prompt questions were an object's material form, purpose and uses.

\section{The modern experience}

Of all the aesthetic tasks undertaken since the start of the nineteenth century, Heidegger believed the main event of the modern era to be the conquest of the world as enlightenment. This interpretation of the enlightenment focused on a structured image where observers saw themselves as able to award measure and dimension to their surroundings. Thus, the origins of ethnographic discourse were seen as a tool for cultural appropriation (Cicerchia 2055, p. 55).

The analysis carried out by Walter Benjamin exhibited this new approach applied to the particular perspective of the formal simplicity of Mediterranean vernacular architecture. ${ }^{7}$ Benjamin (1996, p. 171) referred to the sobriety of certain spaces as an illusion exclusive to his mind, represented as an image of objects which had not been created with any sort of aesthetic pretence. To him, the surprising beauty of these 'sculptures' was apparent in their sobriety, but in no way matched the many hidden functions that allow commonplace objects to become valuable.

Speaking of Benjamin's views, White believed that people persistently choose surroundings that can always provide new and interesting sensations. The reason for this is that healthy behaviour is naturally inquisitive, adventurous and constantly evolving, and requires surroundings where it can thrive (White 1959). In this regard, vernacular architecture is a form of differentiation that expresses anonymity. 'What is sought and provided is a symbol of an ideal life, with slight variations to suit different individual interpretations or a different understanding of the ethos' (Rapoport 1972, p. 176).

Aware of this idealised vision, Benjamin (1996, pp. 177-178) reflected on the strange obsession of some writers and researchers with a formula for 'satisfying desires' viewed through the distant haze characteristic of leisurely travellers. For this reason, Benjamin spoke of the need to suppress the inevitable fantastic effects to access the depths of the habitual and custom, from where 'the marvellous tree whose fruit smells of proximity' could not but grow. 
However, modernist intellectuals, keen to 'satisfy their desires', came to consider vernacular architecture a cult object ${ }^{8}$ because of its strictly formal elements: functionality, order and clarity, adaptation to surroundings and rational juxtaposition (Valero 2005). Thus, following inviolable aesthetic and moral principles, architects were appointed as the cultural benefactors, the 'soul engineers' of owners and other uneducated or less intellectual bodies. Little interest was shown in the societal pedagogy derived from the new precepts, and there was no interest at all in the vernacular nuances of traditional homes (Wolfe 2010).

\section{The value of vernacular architecture}

In opposition to the value awarded to other popular artefacts, the special value awarded to vernacular architecture derived from specific modernist connotations directly connected to the Noucentisme movement and its clear and orderly architecture. This architecture fitted the industrialised production model to perfection since it could be reinterpreted with extreme simplicity.

However, Noucentisme shunned popular architecture as a source of formal inspiration since it bore no relation to architectural styles and could not be taught academically (Pizza 1995). The modern perception of vernacular architecture highlighted the shift of modern architectural abstractions towards a new and significant expressiveness (Pizza 2005) which Giedion (1975) would describe as 'new winds' from undeveloped countries. These reflections on architectural models, with their novelty, modernity, purity, style and rationality, were greeted with stupor. Thus, avant-garde travellers projected a new mystical, monastic and even rural image, in stark contrast to locals who viewed their homes as tools for the land, tied to tradition and to the 'depths of the habitual' (GarcíaEsparza 2011b, p. 348).

Faced with the divergence proposed by modernity, Heidegger talks about the past as our 'heritage' that comes to us as a path towards the future. In this sense, Kenneth Frampton (1972) remarks that 'Everything depends on the capacity of rooted culture to recreate its own tradition while appropriating foreign influences at the level of both culture and civilisation [...] any attempt to circumvent this dialectical synthesis through recourse to superficial historicism can only result in consumerist iconography masquerading as culture'. 


\section{Preservation of cultural value}

As Benjamin (1973) argued, the exhibitive value of photography was responsible for any cultural connotations that might be present in art. The cultural value of historical objects found its ultimate refuge in the cult to memory, which represented free and serene beauty, in direct contrast to exhibitive value. Therefore, art became detached from its cultural foundation in the age of technical reproductivity.

Preserving iconography meant keeping a distance from the creators and inhabitants of popular culture. This led to the belief that, when speaking in terms of distance or closeness in all evolutionary processes of culture, it was imperative to preserve cultural value as a means of remaining close to the local people. However, this belief did not automatically entail the complete preservation of more recent iconographic images for the simple reason that it isolated, sectorised and museified parts of a process which ought to be slow and continuous (García-Esparza 2011a).

During the first decade of the twentieth century, some architects, influenced by avantgarde architectural trends and helped along by the burgeoning media, echoed the lessons of the past to identify the essence of its architecture. They managed to do this without forgetting the moment they lived in, paying attention to the demands of life and available technical advances. In consequence, the architecture stemming from those precepts blended into the landscape, growing roots in the land without cancelling out true popular constructions (García-Esparza 2011b p. 353).

Heidegger's reflections on art and architecture could also partly be responsible for this specific approach to construction, which some experts saw as either a nostalgic return to true construction or a step back or mere paralysis of certain styles and periods. Simple figurative appropriation has shown that the concept of idealised object is in crisis given that it lacks cultural support to justify its day-to-day survival. It is therefore debatable whether other interpretations of the phenomenon would be more successful in improving the status of contemporary vernacular architecture in all evolutionary processes of culture.

When speaking of vernacular architecture as a new approach that can no longer be reduced to a formal manipulation of specific parameters such as touch or vision (Leach 2005), David Kolb (1990, p. 140) uses the subjective devices of irony and parody to comprehend architecture's fragility against the passage of time. Its future relevance in terms of formal perception, purpose and suitability is entirely dependent on this approach (figure 2). 


\section{Techno-science, a colonising and global epistemology}

The post-modern world is frequently described as non-traditional. Given that vernacular architecture is part of time-honoured tradition, its deconstruction and the presence of external influences are perceived as radically anti-traditional. Equally, the post-modern world exhibits strong static relations with vernacular architecture since modernism was responsible for the establishment of its own cultural patterns. These patterns are standard, universal and independent from any specific particularities of socio-political geography that may be reinterpreted and assimilated into heterogeneous contexts (Heller 1991, pp. 120-121).

In short, this is a field where patterns of action and technology are universalised and directly affect the features and elements of vernacular architecture. This makes it necessary to modify the mindsets of researchers so that they can bring the process up to date through an understanding of the socio-economic and cultural background of each geographical location.

This plurality is not meant for our judgment or manipulation. Above all, it lacks a modern treatment and definition in terms of subject-object and certainly does not seem to fit the traditional assumption that there is only one true way amid plurality. The result is not unlike the reality of the practical person who has to live in a 'global' world (Kolb 1988, p. 269).

\section{Colonising and traditionalist paradigm}

'Now everyone can read what is said about the technological world in any competent publication. It is one thing to read it or have news of it, but recognising what was read and stopping to think about it is something quite different' (Heidegger 1989, p. 24).

In other words, thanks to intellectual globalisation, techno-science has generated means of communication and knowledge that distort the epistemology of the vernacular when examining historic and local socio-cultural realities. It is not possible to ignore a new vision of the world, now considered an irreversible phenomenon of 'invasive and colonising' knowledge between individuals and societies. This applies to both overall and specific interpretations of this new paradigm.

This situation expresses the need of many 'developed' societies, to turn their gaze to roots and traditions - often those of 'under-developed' societies - in order to escape from the modern homogenising processes found in their own vernacular architecture. Researchers are oblivious to the fact that their influence may contribute to the 
homogenising process, depriving other societies of their own particular cultural development (Huyssen 1981).

Journeys are postulated as a means of escape from everyday life, fleetingly becoming a form of involuntary colonisation by intellectuals avid for new or unconventional experiences, or even just fresh knowledge. Some government officials, organisations or bodies are fully aware when travelling that they are intellectual colonisers of dysfunctions foreign to them. This reflects a form of cultural appropriation that brings no long-term profit for the colonised party, but is generally a source of self-satisfaction for the coloniser.

Thus, at a time where seminars, congresses, scientific journals and other media enable instant international and intercontinental intellectual exchanges, many researchers of vernacular heritage assert their right to a better understanding fully conscious that complete self-awareness cannot be achieved. The scale of culture, history and forms of expression is such that the logical sequence needed for appropriate action is often absent (Kolb 1988, p. 267).

Therefore, the right to knowledge can be applied in very different ways because there is more than one view and there are many other social realities to be understood (Paz 1984). We should be aware that the multiplicity in which we live increases our responsibility and freedom to understand the irregularities of modern social development and this applies indirectly to vernacular architecture.

Researchers focusing on countries with irregular cultural historical evolution, either as a result of alteration or 'invasion' by external currents of thought, need to recognise the existence of a latent detachment from the society of origin. Countries are eager to feign socio-cultural development which most of the time is devoid of content. This applies to vernacular architecture, modern movements and current techno-scientific diffusion. In any case, the field of thought should be in keeping with historical events, evolving simultaneously, since otherwise the lags, distortions, and false awareness and interpretations which nobody ever stops to observe, become all too patent.

All that is needed is to find a path independent of internationally recognised heritage milestones to suit each country's historical process, culture and education. This should reveal the lack of historic awareness and thought which translates into a lack of coordination between what national administrations or international trusts study and recognise, and the reality of everyday vernacular architecture as seen by its owners.

Let's have no illusions. All of us, even those who, you could say, are professionals of thought, are very often poor in thought. We are all too easily lacking in thought. 
The lack of thought is a troubling guest in the modern world, coming and going everywhere. For nowadays we find out everything in the quickest and cheapest way and forget it just as quickly and instantly (Heidegger 1989, p. 17).

According to Heidegger (1989, p. 19), researchers have a reserve of planned thought, with the calculated intention of specific aims but generally lacking in meditative reflection since this entails greater effort. This planned thinking can lead to whitewashing, fakes or recreations arising from complete cultural detachment from local socio-political scenarios and resulting in misguided perceptions, false judgement and simplistic attitudes in the interpretation of vernacular heritage.

In turn, all these factors block the critical sense, inhibit the power of analysis and thrive on comfortable reports and easy solutions. The appearance of a new paradigm and its sociological foundation loses meaning as it does not really influence the spirit of the people or a structured foundation in society. Instead, it whitewashes the reality of a backward world incapable of putting revolutionary ideas into practice.

This acculturation goes beyond epistemology, psychology or aesthetics. It can also bring about distorted traditionalist contents resulting from imported ideas latent in mass communications and irrelevant to local reality. These contents have a masking effect, are difficult to understand and will later come to be reinterpreted or misunderstood. These utopias are hard to translate economically, materially, ideologically or even aesthetically due to the influence from a universe outside reality itself.

At times, reality reflects the primacy of socio-cultural elements and of specific ideas and transformations. Many ideas and changes in vernacular architecture are not prompted by physical needs, but rather by changes in image, symbols or fashion. The impact of ideas and attitudes on basic needs is quite surprising. It should be questioned whether usefulness, the appearance of usefulness or the image represented by the object are sought. Nowadays, the ideal of prestige or appearance can be a vital consideration for some people when choosing models. Of course, it can always be argued that people are the product of their surroundings and at the same time contemplate surroundings through the eyes of their product (Heller 1991, p. 61).

\section{The suggestion of local flows}

In local international terms, the sense of acculturation takes on different connotations. Some authors speak of generating dynamic or static surroundings to produce architecture that is either a static and closed or a dynamic and open entity. It is a type of 
architecture focused on the emerging potential of places where people can be induced to participate in collective environments as part of the public domain (Thomsen 2008).

As Leach (2005) mentioned, when these agents take part in a performative relationship they are creating the reality which describes the relationship itself. This performative action thus provides something that does not exist anywhere else, something that constitutes a local reality. The effects of performativity are connected to a general feeling born from the interaction of increasing information flows and intercultural elaborations in any society. When speaking of performative processes and objects, these processes can be described as fluid, while objects come to be through the relationships arising from local flow interactions (figure 3).

Therefore, further thought on the interaction between acculturation and ethnocentricity is required to obtain positive results when incorporating the new techno-scientific paradigm into society. Thus, the paternalistic institutionalisation of culture widens the gap between specialised culture - restricted to a few select experts - and the hermeneutics of the daily life of normal people. 'Conservative' or 'neoconservative' experts usually consider the advance of research towards technical progress and the structuring of information and images to be separate from a direction for the orientation of daily life (Solé 1998, p. 206).

The experts involved in heritage are normally architects or engineers who focus their findings exclusively on the building and their own speciality. Interventions are usually carried out without prior knowledge of the habits and customs of how local people build, repair, and maintain their dwellings. These interventions should apply knowledge from other experts in the fields of social sciences and geography. In order to undertake proper interventions in each vernacular settlement it is necessary to carry out a multidisciplinary and comprehensive analysis of the physical suitability of the buildings and the psychological suitability for the inhabitants.

It could be said that from an international context rural societies are dependent on other societies, which set their objectives in search of distinctiveness, ethnicity, national identity or economic development (Seamon 1978). For this, other hierarchised societies are used as reference following specific 'modernisation' strategies. Nettl and Robertson (1968) considered this significant in the context of the national elites, which are trying hard to develop the same societal attributes as those nations considered most prestigious. For Kenneth Frampton (1982, p. 176) this is entirely dependent on whether the rooted culture is capable of recreating its own tradition while appropriating foreign influences pertaining to culture and civilisation. 
According to Gleick (1999), 'acceleration is the basis of just about everything in life'. Speed appears as both a blessing and curse in the Modern Age, where the contemplation so characteristic of traditional societies is found to be replaced by sensation, simultaneity, immediacy and impact (Bell 1977). This acceleration transforms identity into something transient (Rosa 2005).

Other authors speak of an 'empty' time moving increasingly faster because of so-called technological progress, which has become independent from religious origins, motifs and symbols, ultimately becoming profane (Beriain 2008). In this sense, the 'new roots' appear to be connected with a serenity towards things, a way of reliving the former roots which so quickly disappear (Heidegger 1989, p. 28). For Redfield (1956), roots are distinctive in a rural society whose way of life and culture, as defined by Malinowski (1970), remain closely linked to the countryside, with economic, sentimental and traditional ties to social groups, ideas, customs and human beliefs (figure 4).

\section{Thoughts on the new praxis. Interaction or control}

Early twenty-first century rural space is extremely complex when it comes to its uses and purposes. This contrasts with the clearly-defined polarisation between vernacular dwelling and urban housing ${ }^{9}$ present in the first half of the twentieth century, when part of the population, inspired by different ideologies, reacted to urban development with an anti-urban feeling by creating associations for the protection of landscape and its heritage.

Nowadays, as Sempere and Tulla (2008) pointed out, the purposes of rural space are connected with the compensation of urban needs, both physical and psychological. Thus, rural space is not a merely economic surrounding but rather a social and environmental one, whose dynamics are avidly analysed and researched by urban intellectuals. As a result, rural needs go on to become a peripheral part of urban understanding, as well as resembling it.

Modernity's precepts of inertia are currently followed in the psychological process by which the urban individual appropriates rural culture. However, this takes place in a new dimension of constant permeability and hybridisation through a transformation process in which the rural individual, in turn, idealises urban surroundings. These processes must be accepted in full awareness of the progress of socio-cultural diversity (Hisrscon 1998). And so, it is necessary to encourage a genuine critical awareness (González 2003) to articulate the mechanisms local society requires to understand the necessity for preservation of specific architectures or spaces. Built places embody memory, needs or 
ideas materialised from individuals or groups in a specific space and time (Landow 1971).

We have complex historical identities that do not merge into local play. In engineering a place for ourselves we need to find ways to discern the languages and projects surrounding us. Although Kolb (1990, p. 170) holds that there is no fail-safe way to discern these, we should make do with the possibilities and movements that our location offers us. There are choices and standards, but no ultimate standards. Our values are tied to history and to who we are, and there are many ways in which they can be approached, discussed and judged. In Kolb's (1988, p. 270) words, 'modernity offered secure grounding in the unity of the self or the formal total picture' (figure 5).

\section{Norm and action}

In the mental displacement between the ideals of urban surroundings and the pragmatism of rural surroundings we must analyse how the norm operates over action. Rural pragmatism is attained through customs, a group of norms akin to regulations that also resemble recommendations. Building customs can be considered a sort of habit, a tendency to do similar things on similar occasions or in recurring circumstances. Customs are social habits, behaviour patterns acquired over the years. Customs place regulatory pressure on the members of a community. However, unlike regulations, customs are not dictated or promulgated (Wright 1970, pp. 27, 111).

In contrast, the urban ideal is attained through technical norms, which affect the operativity of local construction. In this sense, technical norms tackle technical building solutions based on standardised or homogeneous norms that have been developed following urban thought and regulations. Rural pragmatism, as defined by Wright (1979, p. 118), attends to the particularities of vernacular solutions and its contemporary adaptations, not regulated as law, but more as a practice or custom. Sometimes vernacular solutions can be implemented by local experience to comply with the demands of building regulations without adhering strictly to the standardised norms.

The existence of norms is a fact, but the issue surrounding the truthfulness of principles depends on how useful they are to the agenda of those promoting them. Therefore, we should maybe talk about 'acceptability' or 'plausibility' rather than 'truth'. In this sense it could be said that the norm, as a sort of mandate, seems to be the only resource employed exclusively in certain societies - those which historically have lacked profound teaching and cultural processes - to encourage people to carry out a given action either repair, replacement or reconstruction - in a specific way (Wright .1970, p. 133). 
According to Buttimer (1980), this difference may be of use to us in understanding the needs, values and desires of people. Myths still exist for modern humans: some people repair and adapt their homes following popular values and thoughts rather than the order and design of urban subculture. This effectively means that ambiguities are to be found in the creation or adaptation of some contemporary building environments.

In this sense, and going back to Heidegger's earlier thoughts, the norm can be glimpsed as an operative sub-product of a planned thought that is in opposition to collective consciousness. As collective consciousness becomes more rational and reflexive, the norm becomes less imperative and therefore encourages the free development of individual characteristics. Durkheim (1966) has underlined the need for careful consideration to harmonise heritage, the collective consciousness and customs of nationalism, and the cosmopolitanism and normativity of universalism (Figs. 6 and 7).

\section{Conclusion}

I would like to point out that conservation policies are closely related with the way each society values and views its roots and traditions. If these policies to educate society are a relatively recent development in each nation or region, these areas run the risk of allowing their values to be gradually taken over by contemporary and external transformations. The general context of this study is Europe and it focuses particularly on European countries where democratic processes are relatively recent, such as Portugal, Spain, Greece, Italy, and others; although in any case, each reader should consider whether these processes also occur in his or her country.

Present reflection exposes a criticism of the processes of 'development' carried out without thought or consensus; a critique of a form of behaviour affecting contemporary vernacular architecture. Thus, the performance of many professionals in environments, places and cultural spaces whose social content they have no knowledge of, can lead to erratic attitudes, either superficial or picturesque.

In these sense, international orientations have to be found to establish clear ways to confront all aspects currently affecting the dynamics of vernacular architecture in each region. However, this cannot be achieved applying standard targets to all the different situations, since each society has its own backgrounds, perceptions, hopes and desires, and these are not the same across the board. A new paradigm must be applied to each region in each country but need not necessarily follow trends or impositions from abroad. In fact, researchers should simply apply international trends and knowledge to each cultural, educational and socio-economical situation using dialogue to improve the way 
in which vernacular architecture is conceived and assessed by both locals and intellectuals.

In agreement with Kolb's words, this study uses shifting discourse and contexts to discourage absolute claims. This should not be seen as conflict. Dialogue is essential and therefore open discussion and participation from the community must be embraced. Self-examination and reflection on our own weaknesses and limitations should be encouraged. Nevertheless, rational agreement is only one of many appropriate, disciplined forms of evaluation, and being argued into changing our beliefs is only one way of altering the language we speak.

According to Durkheim (1976), 'just as the vocabulary or grammar of a language are not the work or property of any particular researcher, but the result of a collective manufacture, and express the anonymous collective which use them', bilateral communications favour dialectic exchange as a means of expression and communication for collective representations, but only inasmuch as the different agents share reflections, a critical spirit and discussion.

The current process resembles the moral one in Durkheim, which seeks and expresses a dynamic balance between the needs of rural surroundings and the ideas of urban surroundings. And so, the 'objective or subjective facticity' of vernacular architecture depends on the social context in which it is born, operates and is configured as a dialectic process. Understanding, interaction and plurality come from communication conditioned by and using a shared language. 'Cognitive interpretations, moral ideals and hopes, interests and evaluations are an essential part of this praxis'.

There must be a dialogue between reflections on vernacular architecture and social forces transcending the obligatory nature of norms, resetting goals and creating new ideals and practices to achieve a twenty-first-century vernacular architecture which harmonises values, feelings and rationality to prioritise a new direction for local consciousness as opposed to intellectual colonisation.

The survival of the vernacular - indigenous and sincere, free of whitewashing - should reflect its suitability in terms of the social and historical space it occupies in each society. Thus, the processes for understanding vital spaces should take cultural tradition into account without neglecting the advantages of science and technology. 


\section{FIGURES \& CAPTIONS}

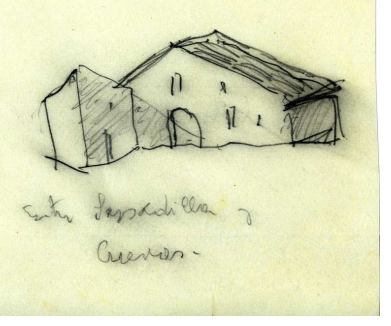

\section{Figure 1}

The analysis of vernacular housing can involve socio-cultural factors and new trends. Its physical nature as connected to geography and its symbolic, cultural and spiritual values have given rise to many representations and interpretations. However, past interpretations of vernacular architecture were linked to images, symbols and fashion. This drawing represents the intellectual discovery of architecture in the early twentieth century. Vernacular construction of an inland area of Valencia, Spain. 1933. Alfred Baeschlin (1883-1964), architect.

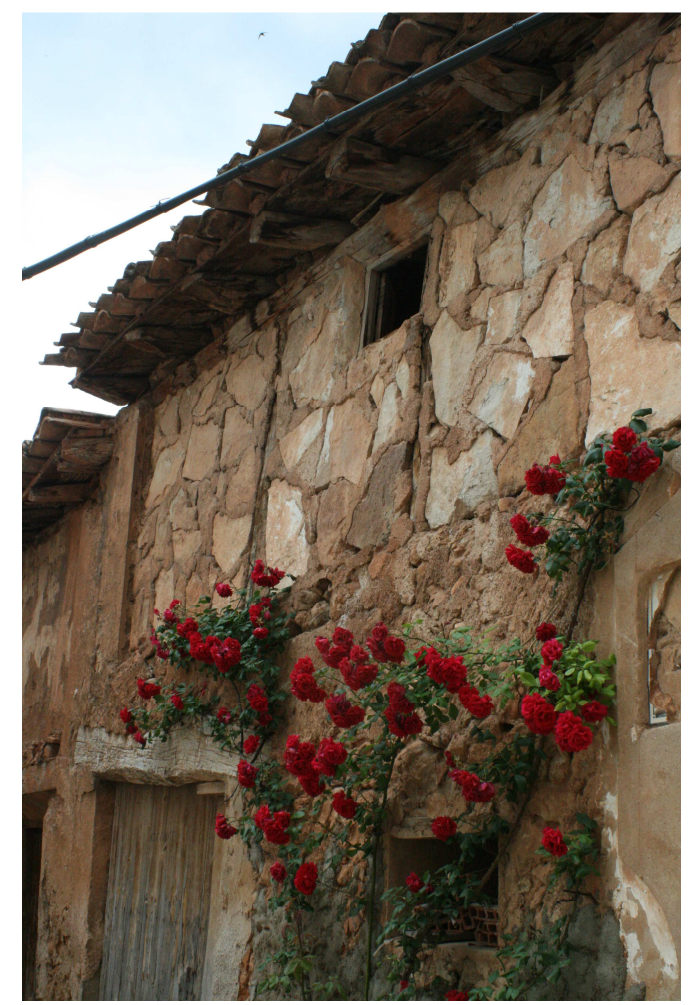

\section{Figure 2}

The iconographic contemporary image of vernacular architecture shows a model of preservation based on respect and reverence towards the incorporation of the buildings within the landscape. These forms satisfy cultural, symbolic and utilitarian needs and it is often difficult to comprehend the location without these forms of settlement. This representation may suggest the vision of rural wellbeing idealised by foreigners or as seen through the nostalgic gaze of the locals. Vernacular architecture of the inner Valencian Region, Torrebaja, Spain. 2008, Juan A. García Esparza. 


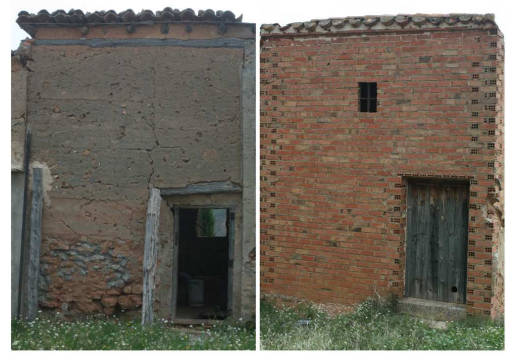

Figure 3

The loss of folk art appears to be related to the excessive amount of options available. In contemporary terms, folk art should be seen not as the result of some obscure taste, but as that of education and having learnt how to choose from a number of alternatives.

In fact, there may be many movements, many different calls and spaces either open or becoming available to us. We have no legal mandate to create options, but we make our way as best we can without guaranteed principles to rely upon. The local transformation process speaks of the survival of local and historic formal aspects. These refer to uses and customs in places in which spontaneous, immediate and economic execution prevails over a merely iconographic one. Inland region of Valencia, Torrebaja, Spain. 2008 Juan A. García Esparza.

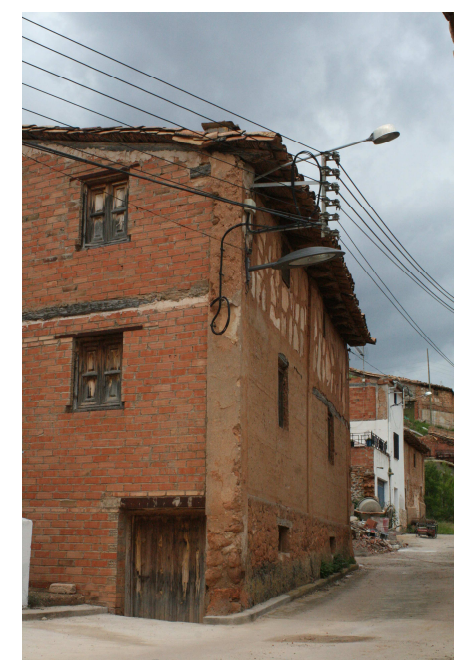

Figure 4

Ehrenzweig describes Gestalt as characterised by brevity, simplicity, purity and ease. In this case, the intervention shows the simple addition of new building materials and solutions according to the epoch, conserving the historical techniques used on the main façade and for the roof assembly. Arnheim described this type of simple solution as conforming to Gestalt given the use of material solutions affecting the least possible number of structural features. The image shows the recovery of a vernacular dwelling which only takes into account the cheapest and most closely available materials, using industrialised brick, which seems to lack sensitivity in terms of form, and also opposes ambiguity within the context of Gestalt. This is the representation of expression aimed at a dynamic balance between tradition, immediacy and style. Inland region of Valencia, Torrebaja, Spain. 2008 Juan A. García Esparza. 


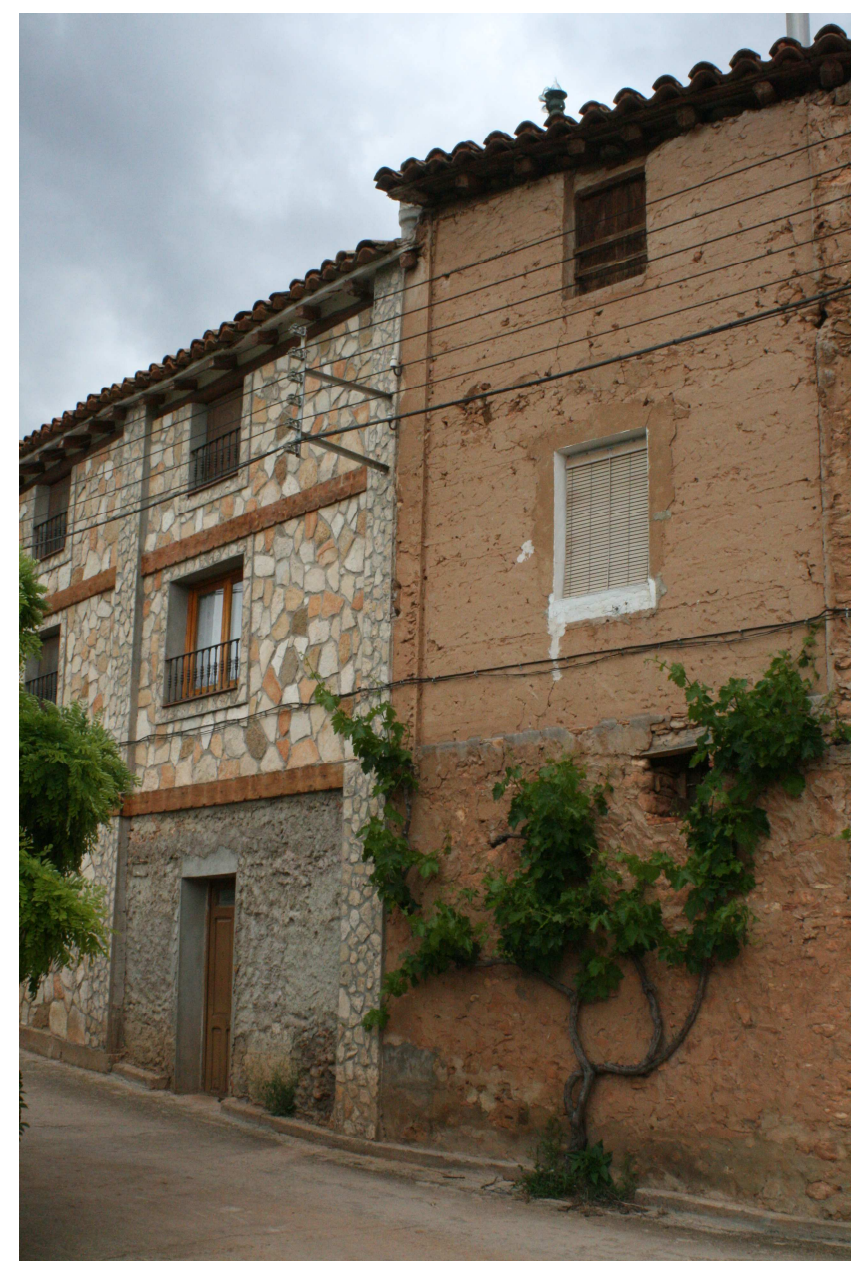

\section{Figure 5}

Ambiguity is attributed to the forms of expression which support more than one interpretation or a duplication of meaning, rather than encouraging doubt, hesitation or uncertainty. Scully referred to a living space in which life could be enclosed, taking into account a certain amount of 'disorder' for which space could not be designed for merely artistic reasons since this could ruin the living conditions. Therefore, it should be stated that vernacular dwellings and historical sites are not completely under the control of the designer (nor should they be). Desires, public opinions, however foolish, and the human need for variety must be taken into consideration.

The adaptation, repair and reinterpretation of vernacular architecture have guided popular customs which have been developing over more than two generations. This reflects hopes and nostalgia linked with the recent past. However, it also reflects the lack of knowledge, teaching and learning of vernacular construction techniques. Establishing standards requires not only a better understanding of the necessary perceptions and their physical counterparts, but also a consideration of the social, political and economic aspects of living space design. The picture shows an example of contemporary interpretation of vernacular construction in an inland region of Valencia, Torrebaja, Spain. 2008 Juan A. García Esparza. 

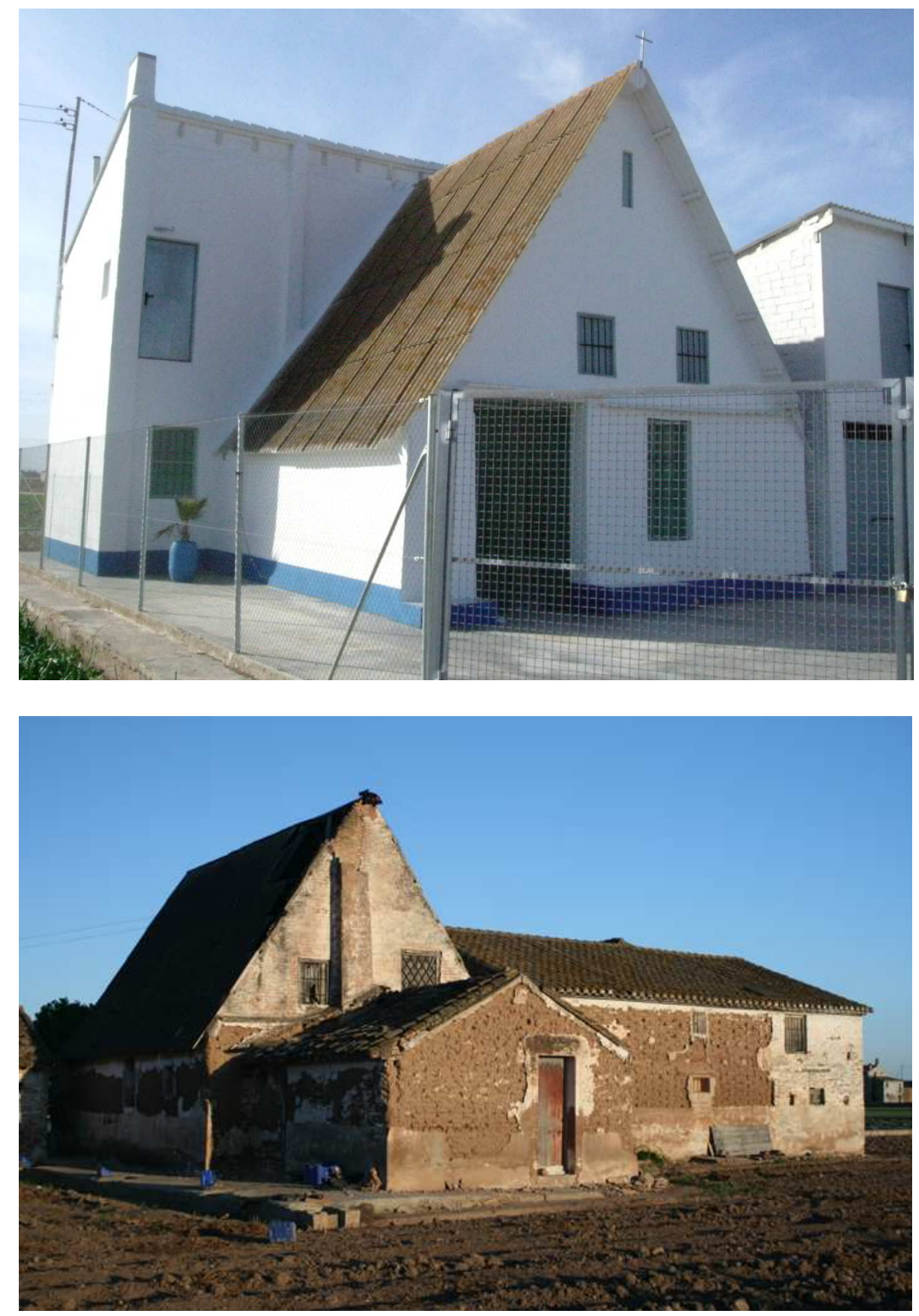

Figures 6 and 7

Some places are changing because of the socio-economic facts of life. Nowadays no single individual or society is consistent enough to build a stable place with a completely solid sense of identity. Any attempt to hold on to preservation as a rigid system could be viewed as a form of imposition. The real problem may well be the idea of a single undifferentiated consumer culture, a common enough idea nowadays, or just another take on the modern attempt to separate form from content.

The free execution shows the preservation of content against image. Here, the historical absence of norms pertaining to the strict preservation of heritage iconography has made it possible to adapt vernacular dwellings to the obvious necessities of each period. This image shows the addition of new materials, constructions or buildings around historic ones without aesthetic pretentions. This was carried out taking into account and respecting the legacy of their ancestors. In the early twentieth century interventions were carried out on constructions up to a thousand years old, situated in the ancient landscape of la Huerta de Valencia, Spain. 


\section{ENDNOTES}

${ }^{1}$ Nietzsche evokes the term Heimat in The Gay Science, as 'we with no homeland'.

${ }^{2}$ The term Heimat is of ancient origin, although in the eighteenth century a small elite of writers and publicists occasionally used the word, which lacked a specific definition. Early romantic writers adopted the term Heimat and began to incorporate it into their vocabulary. Heimat reappeared when the structural politics of the German state were disintegrating. The term then took on a modern connotation which attempted to reorganise and provide understanding of German identity using terms such as Nation, Staat, or Volk.

${ }^{3} \mathrm{Hegel}$ thinks that the values and customs that make up the particular spirit of place have to be immediately accepted, for otherwise people will hold them only as a matter of expediency (Kolb, 1988, 268).

${ }^{4}$ Amos Rapoport (1972, p.94-95) talks about traditions interacting with the settlement as a characteristic of Latin or Mediterranean cities. He also mentions the interaction between traditions and housing as a characteristic of Anglo-American cities. Thus, depending on the context, vernacular tradition, housing, settlements, and landscapes are the products of a single cultural system and a single world picture.

${ }^{5}$ As regards the words of Norberg-Schulz (1979) the existential space or anthropological place, constitutes a body, charged with meanings which are studied by cultural anthropology. This body is charged with an expressive potential discovered by people, activated with their perception and existence, and imbuing the location with a series of meanings derived from its culture, collective and personal memory, and experiences. These are not only material elements, but also elements linked to the subjectivity of each observer.

${ }^{6}$ In which the actor, the settler, consciously practices tradition or subconsciously awards values which are equally valid. 'If therefore, anthropological space is both geometric and historical, which it is insofar as its inhabitants can recognize references which are not a result of knowledge, but is a place built by their ancestors, which follows the rhythms of nature and human activity in the environment, the anthropological place lives in history, it does not make history' (Augé 1992, p.55-69).

7 The movement surrounding the analysis of Mediterranean vernacular architecture involved many Central European intellectuals and artists wanting to experience new sensations or simply escape hostile environments following the First World War. Travel was a reflection of some existential angst and feelings of decline in apparent reference to a bleak future. There was perhaps some reticence to the social and political legacy of historical models, from which intellectuals could not disengage, or move on in their 'start from zero'. Anti-bourgeoisie travellers fled from Central Europe to Greece, Algiers, Italy and Spain, where they mostly settled in Ibiza and the Canary Islands.

${ }^{8}$ The GATEPAC journal published several issues on this. "Ibiza, la isla que no necesita renovación arquitectónica" $A C$ no. 6, 1932; "La arquitectura popular mediterránea" $A C$ no. 18; "La arquitectura popular mediterránea" $A C$ no. 21, 1936.

${ }^{9}$ Amos Rapoport (1972, p. 168) connects vernacular dwellings with the term folk, and urban housing with style. In addition, Kimberly Dovey (1987), talks in terms of LivedSpace vs Geometric Space. 


\section{REFERENCES}

Appelgate, C., 1990. A Nation of Provincials. The German Idea of Heimat. Berkeley: University California Press, 10.

Augé, M., 1992. Non-lieux. Paris: Seuil, 55-69.

Augé, M., 1998. Hacia una antropología de los mundos contemporáneos. Barcelona: Gedisa.

Beardsley, M. and Hospers, J., 1976. Estética, historia y fundamentos. Madrid: Cátedra.

Bell, D., 1977. Las contradicciones culturales del capitalismo. Madrid: Alianza, 109.

Benjamin, W., 1973. Discursos interrumpidos I. Madrid: Taurus.

Benjamin, W., 1996. Escritos autobiográficos. Madrid: Alianza, 171.

Beriain, J., 2008. Aceleración y tiranía del presente. La metamorfosis en las estructuras temporales de la modernidad. Barcelona: Anthropos, 100-101.

Boa, E. and Palfreyman, R., 2000. Heimat, a German dream, Regional loyalties and National Identity in German Culture 1890-1990. London: Oxford University Press, 23.

Buttimer, A., 1980. Social space and the planning of residential areas. In: Buttimer, A. \& Seamon, D., ed. The Human Experience of Space and Place. London: Croom Helm, 22-23.

Cicerchia, R., 2005. Viajeros ilustrados y románticos en la imaginación nacional. Buenos Aires: Troquel, 55.

Dovey, K., 1987. "Putting Geometry in its Place". In: Seamon, D., ed. Dwelling, Seeing and Designing, New York: State University Press, 247-269.

Durkheim, E., 1966. Leçons de sociologie: physique des mœurs et du droit. Buenos Aires: Schapire, 87.

Durkheim, E., 1976. Educación como socialización. Salamanca: Sígueme, 40.

Frampton, K., 1982. Modern Architecture and the Critical Present. London: Architectural Design. García-Esparza, J.A., 2011a. Barracas on the Mediterranean coast. International Journal of Architectural Heritage, 5 (1), 27-47.

García-Esparza, J.A., 2011b. El descubrimiento cultural de la arquitectura popular en España. Alfredo Baeschlin (1883-1964) y el influjo centroeuropeo. Thesis (PhD). Universitat de València, 348.

Giedion, S., 1976. II punto sull'architecttura contemporánea. Da Bruxelles ad Atene: la Città Funzionale, 9 (52), 34.

Gleick, J., 1999. The Acceleration of Just About Everything. New York: Vintage.

González, A., 2003. Crítica de la singularidad cultural. Barcelona: Anthropos, 201.

Heidegger, M., 1989. Serenidad. Barcelona: Serbal.

Heller, Á., 1991. Historia y futuro. ¿Sobrevivirá la modernidad?. Barcelona: Península.

Hisrscon, R., 1998. Antropología reflexiva. In: Lisón, C., ed. Antropología: Horizontes teóricos, Granada: Comares, 162.

Huyssen, A., 1981. The search for tradition: Avant-garde and post-modernism in the 1970s. New German Critique, (22), 24-25.

Kolb, D., 1988. The Critique of Pure Modernity. Hegel, Heidegger, and After. Chicago: The University of Chicago Press.

Kolb, D., 1990. Postmodern Sophistications. Philosophy, Architecture, and Tradition. Chicago: The University of Chicago Press.

Landow, G. P., 1971. The Aesthetic and critical Theories of John Ruskin. Princeton: Princeton University Press.

Lanternari, V., 1981. Sensi. In: Einaudi, G., ed. Enciclopedia Einaudi, vol XII. Turin: Einaudi, 742746. 
Leach, A., 2005. Tafuri and the Age of Historical Representation, Architectural Theory Review, 10 (1), 1-18.

Lévi-Strauss, C., 1987. Race et historie. Paris: Denoël, 63.

Malinowski, B., 1970. Una teoría científica de la cultura y otros ensayos. Barcelona: Edhasa, 39. Martínez de Pisón, E., 2005. Paisajes de letras. In: Ortega Cantero, N. ed. Paisaje, memoria histórica e identidad nacional, Madrid: U.A.M., 47.

Nettl, J.P. and Robertson, R., 1968. International System and Modernization, London: Faber\&Faber, 145.

Norberg-Schulz, C., 1979. Genus Loci. Paessagio, ambiente, architettura. Milan: Electa.

Ortega, N., 2005. Paisaje, memoria histórica e identidad nacional. Madrid: UAM - Fundación Duques de Soria.

Paz, O., 1984. La Fleury saxifrage. Paris: Gallimard, 77-78.

Pizza, A., ed. 1995. Josep Lluis Sert y el Mediterráneo. Barcelona: Col-legi d'Arquitectes de Catalunya - ํำ de fomento, 58.

Pizza, A., 2005. Sincretismos mediterráneos, In: AA.VV., ed. A.C. La revista del G.A.T.E.P.A.C. 1931-1937, Barcelona: Papeles dc ETSAB-UPC, 247.

Rapoport, A., 1972. Vivienda y Cultura. Barcelona: Gustavo Gili.

Redfield, R., 1956. Peasant Society and Culture. Chicago: University of Chicago Press, 27.

Rosa, H., 2005. Beschleunigung. Die Veränderung der Zeitstrukturen in der Moderne. Frankfurt: Suhrkamp, 364.

Seamon, D., 1979. A Geography of the Lifeworld. Movement, Rest and Encounter. London, Croom Helm London, 148.

Sempere, J. and Tulla, A.F., 2008. El debat teòric sobre el periurbà i la concreció d'un plantejament urbanístic en un entorn complex: el cas de Barcelona i Toulusse, DAG, (52), 112130.

Solé, C., 1998. Modernidad y modernización, Barcelona: Anthropos, 206.

Thomsen, B. S., 2008. Performative Environments: Architecture Acting with Flows, Architectural Theory Review, 13 (3), 320-336.

Valero, V., 2005. Ibiza, la tradición seductora, In: AA.VV., ed. A.C. La revista del G.A.T.E.P.A.C. 1931-1937, Barcelona: Papeles dc ETSAB-UPC, 259-261.

White, R.W., 1959. Motivation Reconsidered: The Concept of Competence, Psychological Review, (LXVI), 297-333.

Wolfe, T., 2010. La palabra pintada \& ¿Quién teme al Bauhaus feroz?. Barcelona: Anagrama, 155-157.

Wright, G.H. von, 1970. Norma y Acción: una investigación lógica. Madrid: Tecnos.

Xirau, J., 1969. Manuel B. Cossío y la educación en España, Barcelona: Ariel, 42.

Zugni-Tauro, A. P., 2000. Fienili, rustici, case dominicali e ville nal Feltrino. In: Pasinato, A, ed. Heimat, Identitá regionale nel processo storico, Roma: Donzelli, 184. 